
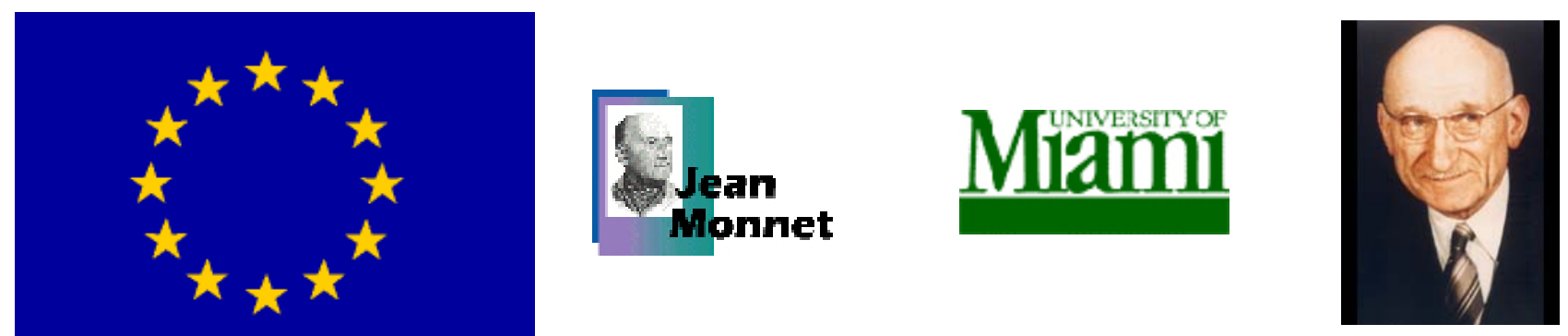

R. Schuman

Miami-Florida European Union Center of Excellence

Between cherry-picking and salvaging the Titanic: Spain and the rescuing of the essence of the $\mathrm{EU}$ Constitution

Joaquín Roy
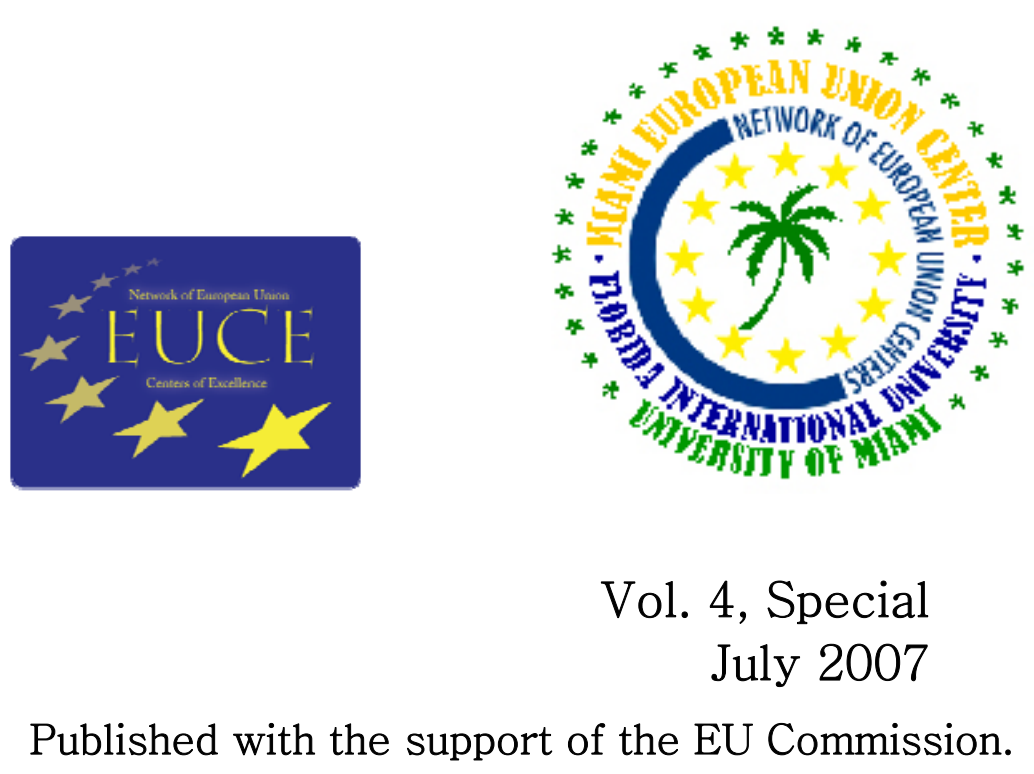

Published with the support of the EU Commission. 


\section{EUMA}

European Union Miami Analysis (EUMA), Special Series, is a service of analytical essays on current, trend setting issues and developing news about the European Union.

These papers are produced by the Jean Monnet Chair, in cooperation with the MiamiFlorida European Union Center of Excellence (a partnership of the University of Miami and Florida International University) as an outreach service for the academic, business and diplomatic communities.

Among the topics to be included in the series, the following are suggested:

The collapse of the Constitution and its rescue

$>$ Turkey: prospects of membership

$>$ Immigration crisis and cultural challenges

$>$ Security threats and responses

$>$ The EU and Latin America

$>$ The EU as a model and reference in the world

$>$ The Common Agricultural Policy and other public subsidies

$>$ The euro and the dollar

$>$ EU image in the United States

These topics form part of the pressing agenda of the EU and represent the multifaceted and complex nature of the European integration process. These papers also seek to highlight the internal and external dynamics which influence the workings of the EU and its relationship with the rest the world.

Miami - Florida European Union Center University of Miami 1000 Memorial Drive 101 Ferré Building Coral Gables, FL 33124-2231

Phone: 305-284-3266

Fax: (305) 2844406

E-Mail: jroy@miami.edu

Web: $\underline{\text { www.miami.edu/eucenter }}$
Jean Monnet Chair Staff:

Joaquín Roy (Director)

Astrid Boening (Assistant Editor)

Eloisa Vladescu (Research Assistant)

María Lorca (Research Assistant)

Miami-Florida European Union Center

Nicol Rae (Co-Director), FIU 


\title{
Between cherry-picking and salvaging the Titanic: Spain and the rescuing of the essence of the EU Constitution*
}

\author{
Joaquín Roy*
}

University of Miami

Within the context of the prevailing situation that came about as a result of the rejection of the EU constitutional treaty in 2005 and the subsequent inefficient reflection period, Spain has been faced with several options and scenarios. Each presents risks and opportunities in terms of contributing to the rescue of the original text, its possible transformation, or its termination. In any event, it appeared that the Spanish leadership wanted to make the point that if "Europe is the problem, Spain is the solution", rewriting Ortega's historical assessment (Ortega, Obras). This paper first analyzes the options, scenarios and possible outcomes, with a special emphasis on the activities led by the new Spanish government elected in 2004. It then concludes with a commentary on the contribution to the agreement made at the end of the German presidency of the EU in

\footnotetext{
- Paper presented at the Conference on the EU Constitution, held at Dalhouise University, Halifax, Canada, on May 22-23, 2007. The author would like to express his gratitude to Finn Laursen, Director of the EU Center. An earlier version was summarized as a presentation at the conference on "The EU enlargement and the Constitution" held at Florida International University as part of the commemoration events organized by the Miami-Florida European Union of Excellence (a partnership of with the University of Miami)" on March 30-31, 2007. Recognition is also extended to Leonardo Capobianco and Eloisa Vladescu, Research Assistants at the EU Center of the University of Miami, for their bibliographical and editing help.
}

* Joaquín Roy (Lic. Law, University of Barcelona, 1966; Ph.D, Georgetown University, 1973), is Jean Monnet Professor of European Integration, Director of University of Miami European Union Center and CoDirector of the Miami-Florida European Union Center of Excellence. He has published over 200 academic articles and reviews, and he is the author, editor, or co-editor of 25 books, among them The Reconstruction of Central America: the Role of the European Community (North-South Center, 1991), The Ibero-American Space/ El Espacio Iberoamericano (U.Miami/University of Barcelona, 1996), Cuba, the U.S. and the HelmsBurton Doctrine: International Reactions (University of Florida Press, 2000), Las relaciones exteriores de la Unión Europea (México: UNAM, 2001), Retos de la integración regional: Europa y América (México: UNAM, 2003), La Unión Europea y el TLCAN (México: UNAM, 2004), The European Union and Regional Integration (Miami: EU Center, 2005), La Unión Europea y la integración regional (Buenos Aires: CARI/ U. Tres de Febrero, 2005), Towards the Completion of Europe (Miami: EU Center, 2006) and A Historical Dictionary of the European Union (Scarecrow Press / Rowman \& Littlefield, 2006). He has also published over 1,300 columns and essays in newspapers and magazines. Among his awards is the Encomienda of the Order of Merit bestowed by King Juan Carlos of Spain. 
June of 2007, opening the way for a new Intergovernmental Conference and "Reform Treaty”.

$\underline{\text { Anniversaries and symbols }}$

The year 2007 was considered to be decisive for the EU organization for the coincidental reason that, fifty years earlier, the EU took its second daring step with the Rome Treaty of March 1957, which transformed the initial European Coal and Steel Community (ECSC), officially born in 1951, by incorporating the European Economic Community (EEC) and the European Atomic Energy Community (EUROATOM). The new entity was collectively and legally called the European Communities. Then it was simplified to be known as the European Community (EC), though it would come to be popularly called the Common Market (which is only one of the fundamental ingredients of the EEC), a label still used by generations of Europeans.

This thoroughly economic dimension signaled that the new creation had made it to the third stage of economic integration. It had also graduated from the second stage, the Customs Union, which imposed a system of common tariffs. It had come a long way from the ECSC, the first experiment that included (in a limited common market) only two products. However, these products were strategic and necessary to produce weapons. The new entity was intended to "make war unthinkable" and eventually "materially impossible".

In the mid-1980s, almost three decades after the Rome Treaty, the architects of the experiment realized that in order to complete the Common Market, as contracted in 1957, they would need to issue and implement over three hundred individual regulations. This was the only way to guarantee the full circulation of goods, capital, services, and people. And so Jacques Delors, president of the Commission, the EC's executive body, convinced the Council of the need to approve the Single European Act (SEA) in 1986, which would also paved the way for the Maastricht Treaty (1992) that created the European Union.

The EU was then strengthened considerably by two bold moves. First, the EU adopted the euro as a common currency (anchoring the fourth level of integration, a monetary union). The impasse of the constitutional process marks its presence five years since the adoption of the euro by 300 million citizens in the thirteen countries of the EU, as well as a handful of mini-states that had previously used the currencies of the EU Member States. The euro was a success in all basic monetary operations. Although the dollar remains dominant in terms of the setting of prices and tallying debt, as an exchange currency the euro is on the verge of surpassing it. And while the dollar remains ahead of the euro as the official reserve currency, the euro is catching up in this regard as well. ${ }^{1}$

Second, the EU proceeded to execute the most spectacular broadening in its history --it almost doubled in size-- with three phases of additions. In 1995, Austria, Finland, and Sweden were incorporated, once they exhausted their "neutral" stance during the post-war period. Then in 2004, ten countries were added in a single move, eight of which had been part of the Soviet bloc for almost sixty years, plus Cyprus and Malta. And at beginning of 2007, two other countries, Romania and Bulgaria, joined the EU,

\footnotetext{
${ }^{1}$ For a review of the performance of the euro, see Lorca 2007.
} 
bringing the total of members to 27. The EU already comprises half a billion people. All of this has been accomplished in just fifteen years since the end of the cold war. ${ }^{2}$

However, while these two ambitious moves proved to be highly successful, the warnings made simultaneously about the need for institutional reform of an organization used to dealing with fifteen more-or-less collegial members have not diminished. In response, the EU committed itself to complete its legal framework with the approval of a constitutional treaty that would serve to codify and update the various proposals to render the integration project more viable and effective and give it an international profile more in keeping with demands of today's complex world. Unfortunately, the Constitution was derailed halfway through the ratification process with the rejection of Dutch and French voters.

With the project put on hold until more favorable conditions would emerge, observers had been looking towards the German presidency of the EU in the first semester of 2007, keeping an eye on the results of France's April-May elections. The energy of the German government and the disposition of the new leadership in Paris would certainly determine the future course of the EU. Attention was given especially to the expectations raised by the Berlin Declaration, issued by the German government on March $25^{\text {th }}, 2007$, the $50^{\text {th }}$ birthday of the EU.

Anniversaries, especially centennials and half-a-century commemorations, are irresistible occasions for defending arguments and counteracting different theses in regard to political and economic processes. Comparing previous times with current circumstances is sometimes a fruitful exercise for deciphering situations that are difficult to grasp and that present a challenge to keen observers and citizens in general. Metaphors and images often provide added value for a better understanding of complex situations.

The European Union, an entity that has been solidly anchored in the evolution of the dramatic events of the last century, has been equipped with metaphorical symbols. Most of its successive stages have been proposed as resembling the chapters of human life and the works of mankind. The EU has been, for example, proposed as a mirror image of an emblematic architectural anchor, the cathedral (Barón, Roy 2003). Built over a period of several years, and in some cases centuries, only experts knew what they were constructing, much like the technocratic founding fathers of the EU. The $50^{\text {th }}$ anniversary of the Treaty of Paris of 1952 founding the European Coal and Steel Community (ECSC), that legally ceased to exist when it exhausted its official fifty-year term and that had been inspired by the Shuman Declaration of 1950 , coincided with the $125^{\text {th }}$ anniversary of the birth of Antoni Gaudí, the creator of the temple of the Sagrada Familia in Barcelona. Fascination surrounding the temple for many stems from its long-sought termination, something that several generations have concluded is beyond their lifespan. This emblematic sample of an unfinished cathedral resembles the long evolution of the EU, with no clear ending (Roy 2003). Other observers have equated the EU to a river that flows rapidly in some parts, very slowly in others, through narrow terrain and over an expanded territory.

More recently (see below), the EU has also been compared with a ship that has run aground, in light of the difficulties surrounding the approval of its constitutional

\footnotetext{
${ }^{2}$ For a comprehensive collection of essays on the enlargement, see Joaquín Roy and Roberto Domínguez, eds., 2006. From a Spanish perspective, see Barbé/Johansson and Torreblanca.
} 
treaty. More precisely, it seems like the EU ship has run into an iceberg, much like the Titanic did a little less than a century ago. Though it belonged to an important class (the Olympic), the Titanic was one of a kind, much as the EU has been to date. Although the Titanic was lost in 1912, it was laid out in 1909. That is a century earlier than the scheduled elections for the EU Parliament, the appointment of the new president of the EU Commission, and the date for the implementation of some of the most innovative aspects of the marooned EU constitutional text. Among them are the new Minister of Foreign Affairs and the more stable EU Presidency. In sum, 2009 (a year confirmed by the Berlin Declaration to make crucial decisions) was set as a new time marker for the EU, similar to the conception date for the Titanic. In the event that some of the alternatives proposed for making the survival the present constitutional project possible are successful, 2012, the $100^{\text {th }}$ anniversary of the Titanic may coincide with the consolidation of the rescuing of the EU "Titanic" constitution. The competing alternative for this operation is the method of "cherry-picking" some of the most special aspects of the EU text.

The essence of the European Union has been the subject of endless debates regarding the true nature, purpose and impact of the most successful regional integration and cooperation scheme among sovereign states that history has ever recorded. However, when in times of relative crisis, loud voices and scandalous cries of concern take the stage to demand the dismantling of the European project or its radical transformation. Alternatively, it is disdainfully exiled to a state of anonymity. After embarking on the adoption of the euro as a common currency and proceeding to its most spectacular enlargement, the EU provided itself with a "constitutional” shroud to cover its ever larger home. The project was derailed in the middle of the referendum process, and threatened with the sinking of the integration ship. Then, calls were made to salvage this European Titanic.

\section{The role of Spain}

As a prelude to the completion of two decades of membership in the European Union (1986-2006), Spain wanted to send a message of leadership in the European integration process. With an impressive participation in the Convention tasks that prepared the text of the Treaty, the new Spanish government that was elected in March of 2004, after the terrorist attacks in Madrid, decided to take a risk and be the first of the group of member states that submitted the ratification process to a public referendum. 76.73 percent of the participating voters (42.3 percent of the actual electorate) said "yes", setting the pace for the rest to emulate. With the failure of both the process brought about by the Dutch and French referendums and the long "reflection" period, Spain again took the lead.

The record of Spain's membership in the European Union is truly impressive. ${ }^{3}$ Even during the second part of the Franco regime, the Spanish dictatorial leadership tried

\footnotetext{
${ }^{3}$ For a selection of classic and recent books on the insertion of Spain in the EU, see: De la Cruz, Areilza Closa/Heywood, Moreno Juste, Gillespie/Youngs, Barbé 1999, Crespo, Jones. Farrell, Bassols, Pipes, Marks, Roy/Kanner 2001.
} 
to cope with requirements that were politically impossible to meet. Admitting that becoming a member was an illusive utopia, the government insisted on maintaining a solid link with the EC institutional structure. Meanwhile, the country's presence in a reconstructed Europe was barely made possible through alternative networks such as preferential trade agreements and security arrangements with the United States, leading to entry into NATO in 1982. At the same time, the work of academics rigorously followed the integration process with the result that, when Spain became a member of the EC, numerous experts and scholars were ready to join the effort and strengthen the resources available in Spanish universities and publishing networks. ${ }^{4}$ At the same time, the best and the brightest of Spain's governmental cadres joined the expanded institutions, taking on positions of responsibility and decision-making (Viñas 2004, 2006; Granell 2002). Spain, in sum, "was not different", as a redrafting of the tourism slogan crafted by the Franco regime would say. It was a European country like any other that was returning to its natural home after a long exile.

In the background of successful EU Spanish presidencies, prominent Spaniards had the experience of chairing the European Court of Justice (Gil-Carlos Rodríguez Iglesias) and the Parliament (Enrique Barón, José-María Gil Robles, and Josep Borrell), holding key positions in the Commission, and filling the newly created position of High Representative for the Common Foreign and Security Policy (Javier Solana). When the process of drafting the Constitutional Treaty was announced, rather than regarding it as a standard duty, Spain became very passionate about the mission.

A review of recent history would also show that the Spanish path through the EU labyrinth offers a perceptive oscillation. Observers can easily note the enthusiasm with which the successive administrations, starting with Felipe González in 1982, approached the process of European integration, priming the supranational path. This pattern would subtly contrast with the fractious ambivalence expressed at times by the government of José María Aznar, more inclined towards an intergovernmental approach, especially during his second term from 2000 to 2004 supported by an absolute majority (Pipes, Roy 2005). In part because of the adventure taken by U.S. President George W. Bush in Iraq, Aznar led the inclination of the "New Europe" towards a neo-Atlantism, damaging the deepening of the EU.

Nonetheless, the Spanish government, the academic community, and the media exerted an impressive influence on making the role of Spain in the Convention process a model of participation. The government (and the representatives of the Popular Party, delegated by Madrid) actively participated in the elaboration of the text of the Constitution. ${ }^{5}$ However, in the last stages of the proceedings of the Intergovernmental Conference (IGC) that took on the task given by the Convention, the government of Spain led by Aznar left the process in a frozen state when it refused to accept the new double majority voting system that modified the line up that had been in effect since the Treaty of Nice. ${ }^{6}$ This decision retarded the process and created poor timing, casting

\footnotetext{
${ }^{4}$ For a selection of the classic textbooks and standard reference works on the EU developed and used in Spanish universities, see: Abellán/Vilà, Tamames, Muñoz de Bustillo, Calonge, Montes, Morata, Aldecoa 2002, Mangas/Liñán, and Fernández Navarrete.

${ }^{5}$ For selected books authored by Spanish protagonists: Borrell 2003, López Garrido 2005, Méndez de Vigo 2005.

${ }^{6}$ For details, see Chary 2004.
} 
further doubts on other electorates and governments eager to obtain last minute advantages of dubious effective power results. Only the electoral victory of the PSOE in 2004 removed this obstacle. ${ }^{7}$ The new government diplomatically consented to a new modification of the double majority, opening the way for the ratification process that proceeded throughout much of 2005 and getting ready for completion at the end of 2006. This was viewed as one of the milestones of the new Spanish foreign policy (León 2004).

The Spanish government then dutifully contributed to the promotion of the project in public opinion circles. ${ }^{8}$ That is the reason why when the period of ratification was announced, Spain decided to lead the pack. Interpreting the internal constitutional mandate with a sense of extreme dignity and importance, Spain not only elected to submit the approved text to a national referendum, but Madrid also scheduled that the Spanish elections as the first of several in February 2005, setting a precedent and an example for the rest. When an overwhelming majority of the (disappointing turnout) participants voted "yes", Spain was on record as being ready to maintain its status of good Europeaness. ${ }^{9}$ Then, the shock came. The negative referendum in France and the Netherlands derailed this rosy scenario.

In spite of the bad omens provided by analysts (Closa, 2004), polls and surveys held in France and the Netherlands, the first immediate reaction to the results of the referendums was of disbelief. Then, doubt about the European process set in. When the initial trauma was overcome, the sentiment about the overall picture of the EU and its constitutional process was a resigned feeling that "no one is perfect". Then, this was followed by a mission to pave the way towards a "resurrection" solution, propelled by a counter attack strategy. Ultimately, there was a feeling of “don't blame me for trying” that emerged to deal with the failure.

\section{$\underline{\text { Governmental assessment }}$}

Few sectors of Spanish society, government, political parties, media, the analytical community, and the scholarly circles have remained absent from the debates on the constitutional process. An attempt to summarize the different stances and positions on the fundamental and detailed aspects of the constitutional text would occupy a space that it not available in this brief monographic essay. ${ }^{10}$ The option is to select some representative samples of official, scholarly, and analytical productions that, as a collective body, would provide a glimpse of the Spanish perception of the impasse, the alternatives available, and the implications for Spanish interests. For this purpose, among the candidates to represent the mainstream lines of thought are a couple of key official

\footnotetext{
${ }^{7}$ See Roy 2005.

${ }^{8}$ See Valcárcel, Navarro, and Política Exterior.

${ }^{9}$ For detailed analysis of this exercise, see Ruiz Jiménez 2004 and 2005, Torreblanca-Sorroza 2005, Torreblanca 2005, and Font 2005.

${ }^{10}$ For detailed analysis, see Kurpas, Torreblanca-Plan B, 2005.
} 
documents produced by the Ministry of Foreign Affairs, a set of analytical papers generated by the Real Instituto Elcano, commentaries that appeared in policy-oriented journals such as Política Exterior, and a bibliographical reference of scholarly products in the form of books and journal articles. ${ }^{11}$

As soon as the reality check produced by the French and Dutch rejections set in, the Spanish government took on the task of commissioning studies on the background, alternatives, and consequences for Spanish interests. In September 2005, the Joint Commission of the Spanish Congress and Senate for the European Union government entrusted the Spanish Ministry of Foreign Affairs (Secretaría 2006) to draft a report. After outlining the most salient aspects of the background of the document, the report stressed the obvious fact that it is a treaty that needs to be approved by each and all of the member states, an aspect that led to the surprising rejection by two founding members. Polls initially attributed this outcome to disagreements on defects in the general scope of the text and the ratification strategy. This simplistic explanation did not take into account the complex domestic issues of the two countries in question (fear of immigration, economic deterioration, citizen alienation).

When the reflection period did not deliver any perceptible results, a line up of different national attitudes in the countries that had already voted "yes" was detected by Spanish governmental experts. First, some countries (with Belgium in the lead) wanted to push the ratification process forward, running the risk of a split in the EU network. While Germany and Italy seemed to share this view, the fear about loosing France in the process signaled a note of caution, a sentiment shared by Spain. A second group of countries was then composed of states that had already ratified the text and would like to salvage it. A third group would be composed of new members of the EU that were still surprised and extremely concerned about having joined an organization characterized by confusion. In terms of the sector of states that had not yet ratified the constitutional treaty, three other groups were also prominent: those that have simply postponed the process, countries that have serious doubts (the UK), and the two that explicitly rejected the text.

In light of this situation, several alternatives were opened up for examination by Spanish experts. Reduced to two, first was the recourse to hold a second referendum in France and the Netherlands. Second was the option of a limited revision of the text. Outside of the realm of the current constitutional treaty, the Spanish analysis contemplated: (1) the elaboration of a new treaty, (2) the use of the possibilities existing in the current treaties, and (3) a limited reform of the Treaty of Nice. The official analysis did not accept as feasible (for legal or political reasons) some extremist measures such as: (1) the separation from the Union of members rejecting the Treaty, (2) a new "Union" ("Europe a la carte") for the states wishing to move forward, and (3) the elimination of the ratification requirement for all and each of the members.

Facing this sensitive and challenging atmosphere, the analysis made by the Ministry of Foreign Affairs recommended taking action with a sense of "responsibility and commitment, combined with firmness and decision”. The reflection period should had been fully exploited, without announcing a magical solution or sending exploratory balloons. A close dialogue with the citizens should had been implemented in line with the European Commission Plan "D” (centered on a strategy of information and explanation

\footnotetext{
${ }^{11}$ As samples of recent analytical works on the Constitution, see: Aldecoa 2003, Mangas 2005, Albertí, Petschen 2005, Esteve/Pi, Freixes, and Ruipérez.
} 
to citizens). Regarding Spanish interests, the impressive record and investment made in the ratification process would always force Spain to do everything possible for the project to continue. However, instead of letting the remaining period to be controlled by national interests, Spain should advocate a European-wide debate.

Moreover, the analysis recalled that Spain's record after twenty years of effective membership has earned it a leadership position among the big five. Instead of sending a catastrophic message of chaos unless the project is approved, a positive stance towards public opinion was considered a better choice. The rest of the reflection period should be then dedicated to selling the EU as efficient, to studying the types of measures that would bring the EU closer to its citizens, and addressing national inclinations and concerns. Pretending that the EU treaty would be fully implemented may be the best tactic to win the citizen's confidence. This would be a remake of the "de facto solidarity" that was the trademark of the foundational stages. Spain should form a strong alliance with veteran states that are committed to the EU consolidation, as well as with countries still pending ratification.

A year later, the Ministry of Foreign Affairs issued a follow-up report (Secretaría 2007) in which the option of renegotiating the standing treaty was discarded, giving way to a partial or limited revision, an alternative defended by several States, although many that have already ratified the treaty would prefer that the changes remain minimal. In any event, the assessment is that a second failure would constitute a serious blow to the Union, most especially if coming from one of the powerful countries. Hence, the revision would have a greater possibility of being ratified if it were to add (a social protocol) or eliminate some items. The variances would include: reducing the text to parts I and II, resulting in a mini treaty (as proposed by French presidential candidate Nicolas Sarkozy), a two-step schedule with a reformed Nice treaty and a new text after 2009 (as suggested by Luxemburg), a "core treaty" (an idea floated by Italian Foreign Minister Massimo D’Alema), and the Plan B proposed by EU Parliament Member Andrew Duff (preserving the Charter, and adding some novelties).

Taking the whole range of attitudes into consideration, there were three main sources of disagreement. (1) First, some considered the principles as being the most important part of the treaty; others, the policies; and a third group (Spain included) thought that the balance and fragile equilibrium should be preserved. (2) Some judged that the most controversial items should be eliminated, others considered that the new text should correct that problem, while still others opted for a combined strategy. (3) The third source of disagreement came from the method of the reform: some rejected the idea of another convention, while others accepted it if it came equipped with a clear agenda.

Considering the daunting schedule that precedes the end of 2009 (budget preservation, new EU Commission, 2009 parliamentary elections, candidacy of Croatia, in addition to several national elections), a proposed end of 2007 intergovernmental conference may have to face a "grand package deal", including several lengthy negotiations. However, this alternative was also considered risky if it was to be tackled at the same time, in an effort to lead toward an option of “enhanced cooperation”. In any event, the first test case would be to see what the March 25, 2007 declaration would consist of and what its consequences would be. A consensus pointed out to the idea that the text should include the achievements of the EU, the values of the European process, and the present and future challenges (the most sensible part) faced by the Union. 
With all this in mind, the report outlined the interests and the position of Spain. First of all, a fact that needs to be stressed is that Spain had ratified the constitutional treaty twice, both in a public national referendum and through parliament. This double coup was the crowning touch to an impressive avant-garde position that Spain has taken since it became a member of the EC in 1986. Therefore, Spain was obliged to maintain its position for the continuation of the agreement as expressed in the text. Spain and the other seventeen countries that have approved the text had the moral obligation to insist that the essence of the treaty be preserved. Hence, a limited implementation could not be accepted as sufficient. In any event, Spain was in a comfortable position. It had fulfilled its obligations and it had no interest in opening a negotiation in which it could loose. The burden of opening the treaty was on the countries that had rejected it or were dubious about it.

The main weapons for Spain were: (1) the solid pro-European consensus built by the two main political parties; (2) the ample ratification margin; (3) the acceptance of a new double majority voting system (but only in the context of a new distribution of seats in the Parliament); and (4) considerable backing of Spanish public opinion. Armed in this way, Spain should be able to act skillfully at the right moment, forging alliances with important members, and maintaining close contact with the main institutions. In this line of thinking, the initiative taken in Madrid set an example and it had also been sending a strong message of leadership.

\section{$\underline{\text { Bold action }}$}

Within this array of alternative scenarios, the Spanish government wished to send a clear message. It consisted of pointing out that the option of proceeding towards the completion of the referendum process, while considering the text still alive and useful, was a valid card to be played. Consequently, as a repeat of the Spanish initiative two years earlier that led to the ratification process, the representatives of eighteen European countries of the EU (with the moral support of two other) met in Madrid on January 25, 2007. These twenty Member States had already approved the constitutional project or had promised to do so (Portugal and Ireland). Only Spain and Luxemburg had ratified the complicated code in popular referendum. The rest had prudently bestowed their seal of approval through a parliamentary process (Torreblanca 2007).

These "Friends of the Constitution", as they called themselves, had a common goal. They yearned for the revival of the approval process. They regret ed with pain that a handful of millions of European citizens had taken as hostages more than 60 percent of the population of the EU, numbering half a billion citizens. Twenty Member States had seen their EU plans derailed and frozen by the stubbornness shown by two dissidents (actually, only a portion of their potential electorates) and the ambivalence expressed by three others (the United Kingdom and the governments of the Czech Republic and Poland).

For this reason, the majority of the Europeanist and federally-inclined population considered that the result, in the first place, was not fair. In the second place, it damaged the general welfare of the EU in a complex and uncertain world that needs the effective action of political blocs and economic conglomerates, equipped with impacting influence 
and political vision. An EU marooned half way, with institutions initially designed for a half a dozen of members, and already housing twenty seven, is not the best way forward.

Faced with this situation, the Spanish government took the initiative and convoked the Madrid meeting to exchange ideas that would help the EU get out of the constitutional trap. The government of Rodríguez Zapatero seemed to have taken the same risk it accepted when coming to power in 2004, when it planned the early referendum as a launching pad of its Europeanist example. Spain delivered magnificently with more than two thirds of the voters saying "yes" to the text.

Nonetheless, the subsequent difficulties of the ratification process advised Madrid to allow for a margin of prudence during the "reflection period" while searching for solutions. This term was exhausted without innovative ideas. Hence, the Spanish government took the initiative, coinciding with the German presidency, of providing an incentive for finding a solution. It was not easy and the meeting ended with no decisions. It was further discovered that even this group of "friends" had contrastive opinions. Under the pressure from other governments, Luxemburg decided to postpone its followup meeting.

The record and the background of the extraordinary Madrid conclave showed that Spain and the most daring allies considered that the text should be further reinforced with social warranties and strengthened by the subsidiarity dimension (respect for state and local sovereignty). They also demanded better protection for the environment, active attention to climatic change, expanded legislation to regulate immigration, an effective energy policy, more precise conditions for new membership, and a deepening of the European security and defense policy.

Other members, using a more cautious approach, signaled that these measures are already present in the existing treaties. The text then should be reduced to codify some of the most innovative initiatives: a stable presidency with a term of two and a half years, extended to two terms in total, a Foreign Minister doubling as Vice President of the Commission, the expansion of the qualified majority vote, and reinforcement of the power of the Parliament. This represented a challenge for the German presidency, facing a unique opportunity to demonstrate leadership and search for equilibrium.

Spanish observers took note that the German presidency elected to draw a "road map" to salvage the substance of the EU Constitution in a reduced version. This strategy was interpreted not only as a calendar, but also as being composed of processes and principles. A close reading of Merkel's address to the European Parliament meant for independent analysts from Madrid that the German political ambitions were too weak, but worth trying out. First, the German proposal could be identified with its own national view. Second, Germany had not yet completed its ratification process, subject to demands of the Constitutional Court. Third, calls from France for a mini-treaty might mean that Germany could elect not to act against French interests and be inclined towards a reformed Nice treaty.

The convocation of the Madrid meeting was the subject of several points of criticism. First, the claim that it interfered with the German presidency plans was not considered valid, because governments such as Spain's have the right to defend their interests and be influential. Second, it is true that the substance of the gathering represented an uncomfortable feeling for the French candidates, placing the issue in the middle of the electoral campaign. Third, it increased the risk of dividing the Member 
States into "good" (the ones that have ratified the text) and "bad" (the ones that have not). And fourth, the move runs the risk of opening a gap in the "yes" camp. Nonetheless, this line of analysis indicated that many countries have called for a Spanish leadership role, a wish that has been cautiously contemplated by the government. Nonetheless, weighing risks and obligations, the Spanish government would have to opt for action. (Torreblanca 2007; López Castillo).

\section{Declining cherry-picking, choosing ship-rescuing}

The Spanish think tank community led the way in the task of fine-tuning the contextual circumstances of the impasse and the alternatives available to Spain. Some observers chose an optimistic attitude; others elected a realistic analysis, while others pressed for the strategy that would prove most advantageous for Spain. ${ }^{12}$ Within the varied range of opinions commissioned by the Real Instituto Elcano, in early 2006, a year after the successful Spanish referendum, Francisco Aldecoa (Aldecoa 2006) pointed out that Spanish opinion went from a decisive backing for the project to considering the Constitution as dead, finally opting to resurrect it. He outlined 14 points to follow when studying the situation.

Regarding the process, (1) Aldecoa came to the conclusion that the problem resided in the political path taken, not in the constitutional details, and that (2) the treaty was reinforced by democratic legitimacy provided by the Convention. Then (3) the Constitution supplied the EU with advances in efficiency and presence in the world. This was an added value, not the cause for the delay. Politically, (4) it had received the approval of the EU Parliament and the ratification of 14 (later 18) countries, representing over $50 \%$ of the European citizens. The problem was not a European concern-it was a domestic issue regarding France and the Netherlands. But the collateral damage (7) was that citizens perceived the EU as ineffective in pursuing its goals. (8) The process had failed because it became national, rather than European. (9) The prevailing Nice framework does not account for an EU of over 25 countries. (10) The delay already extracted a high cost. Ironically, (11) some of the projected constitutional measures were already being implemented. (12) Some of the democracy, efficiency and world presence measures are already irreversible. (13) Some of the political background has been changing (prospects of the (German presidency, the economy). And (14), as the circumstances of 2007 would confirm, some EU leaders had come forward to speak on behalf of the reactivation of the process. The key was to find a political solution for what is a combination of European and national dilemmas.

The Real Instituto Elcano offered an elaborate report (Rodríguez-IglesiasTorreblanca). It was a greatly reduced outline of different scenarios that evolved out of the constitutional impasse and an evaluation of the potential benefits and disadvantages for Spain. First, the report insisted on identifying the divorce between the citizens and the elites on "the direction and content of main European policies". Then, the difficult consensus among the States had led to a freezing of the decision-making process, making future enlargements doubtful and cumbersome. The existing veto power made the

\footnotetext{
${ }^{12}$ The Real Instituto Elcano had earlier issued a study with a much wider scope on the general European policy of Spain (Powell 2005).
} 
revision and ratification procedures inefficient, causing the stalemate. In light of this crisis, the drafters took into consideration the fact that the new policies should meet the demands of citizens in areas such as internal and external security, immigration, energy security, and climate change. There is a need for a more efficient institutional framework, something that will only be possible with a more responsive ratification procedure. Finally, the report called for a more decisive leadership role.

Considering these needs and recommendations, the report then outlined four main scenarios. ${ }^{13}$ The first, the best for Spain and the EU according to the authors, was the rather utopian ratification of the text as it was, or without major changes. Although not the most likely, it could be the fastest way to overcome the difficulties. Backed by the large number of countries that had ratified it, one still has to take the unanimity rule into account. The second scenario is characterized by a will to salvage the Constitution, accepting the modification of the text, in essence, resembling the present treaty. Considered risky because of the demand for unanimity and the difficulty in chopping off the negative parts, a new Intergovernmental Conference (IGC) would dissect the text to rescue the most innovative parts, with the eighteen countries that had already approved the original document in the leading role. This was considered as the best option for Spain, in which it had a golden opportunity to influence and persuade other members. The third scenario was composed of a selective rescue, or cherry-picking of the easiest parts. It could result into a mini-treaty, less ambitious, resembling a reformatted Nice treaty. The risk is that this solution would invite individual states to select their favorite issues and defend them until the end. The key for the success of this alternative framework is to preserve "the equilibrium between constitutional and policy innovation". A fourth scenario was represented by the blunt abandonment of the Constitutional Treaty and starting from scratch, with a new convention and a second IGC, moves that would either be made before the $2009 \mathrm{EU}$ parliament elections or postponed until the panorama cleared up.

While the official attitude was cautious and the selective analytical stance was critical, the Spanish observers are well aware that the option consisting of selecting some of the most fundamental items of the Constitution, as candidates in the formation of an acceptable document for approval, was considerably attractive. Whatever the Spanish calculations were regarding the different scenarios, the reality was that the front of resistance to the approval of the constitutional treaty, if pushed as an alternative to save face, would make the cherry picking method more preferable. ${ }^{14}$ This method was backed by British diplomat John Kerr, who acted as Secretary General of the Convention, simultaneously helping to direct the EU process while looking out for UK interests. Kerr proposed that a selection of items be repackaged in a fancy basket (Kerr 2007).

Taking all of the above into consideration, individual analysts ventured into selecting some specific alternatives in general and some of the most beneficial for Spain

\footnotetext{
${ }^{13}$ Earlier, Closa 2005 outlined six options that could be detected as a base.

${ }^{14}$ Meanwhile, ironically, the internal policies of the single market envisioned 50 years ago, revealed that with ingenuity and marketing, mixed with subsidies provided by the Common Agricultural policy (CAP), the EU was able to produce a luxurious cherry selling for $€ 0.81$ (about US 1.05) a unit.
} 
in particular. Although it was independently developed based on the Titanic metaphor exposed above, and using descriptions based on maritime experience, Araceli Mangas (Mangas 2007) offered a useful parallel with the process of salvaging ships and merchandise after accidents, particularly those that are at risk of sinking. This was not surprising when taking into account that the states, governments, international organizations and the EU in particular have been equated to ships and their leaders to captain and pilots, responsible for sailing safely through seas as rough as the treacherous ones created by the current impasse faced by the European project. Eliminating the first scenario (it was unthinkable that the text, left as was, would be ratified by all states) as outlined by the Elcano committee, Mangas proceeded to present a clear choice: (a) salvaging the ship (the Titanic) by getting rid of unneeded merchandise, heavy loads, and the ballast, or (b) letting it sink and salvaging the most desirable goods.

In the event that the rescue of the Titanic-Constitution was selected, following a damaging collision with the "iceberg" represented by the French and Dutch referendums, two sub-alternatives were offered. They were similar to the scenarios II and III as outlined by the Elcano commission. One contemplated the sinking of the ship and then proceeded to salvage the most precious cargo, previously removed by several smaller boats, and finally transferring it to the safety of the port. The author, in this case, would then proceed to select the items most worthy of being salvaged: the Charter of Fundamental Rights, the clause linking the EU to the Human Rights Convention, the solidarity clause, the enhanced cooperation in security and defense, the popular initiative, the ability of the Committee of Regions to address the Court, the early alert mechanism to allow national parliaments and regions to participate in the legislative process, an enhanced use of qualified majority voting, Parliamentary control over the totality of the budget, the establishment of the position of the Minister of Foreign Affairs, and a more stable presidency. This generous "cherry-picking" was not considered to be the best solution by the expert, a position reflective of the inclinations of Spanish scholars and government officials.

The other option considered by the author was based on salvaging the ship, in its entirety-in other words, not only its "content" but also its "container". It should be composed of a fundamental "Framework Treaty" (abandoning the term "Constitution"), which should be an agreement emphasizing synthesis, supplemented by a "General Treaty". This would be backed by the conviction that the hull (the "framework treaty") was good, that the overall philosophy is still unique in its class, and that it would benefit from the removal of unusable items. The internal elements included essential policies that make the Union work effectively and they were clearly outlined in the General Treaty (containing part III and the remaining sections of other parts).

\section{Time to make a decision}

On the eve of the $50^{\text {th }}$ anniversary of the Treaty of Rome, the German presidency was mandated with the issuance of a Declaration. It was to be a short address, easily understood by the common citizens, but its background ran the risk of presenting it as a convoluted document that encountered difficulties in developing a consensus. Observers (Torreblanca 2007) accurately pointed out that the EU had previously missed the 
opportunity to define itself both at the 50th anniversary of the Schuman Declaration and when the Treaty of the European Coal and Steel Community's half-century term expired in 2002. Josep Borrell, the Spanish president of the EU Parliament, claimed that, in order to develop a declaration based on principles and values, the EU leadership would only have to look at the proposed constitutional treaty and read its preamble, part I and the Charter, key documents that all 25 members had signed and that now some were pretending to ignore. For its part, the Commission insisted on taking measures counteractive to the rejection referendum by stressing the need to complete the internal market, deepen social dimensions, reinforce the space for freedom, security and justice, open up a debate on future enlargements, establish coherence on issues of external action, implicate national parliaments in the legislative process, and achieve an agreement on institutional reform. The Declaration would therefore represent a substantive exercise, rather than just a bland historical commemoration.

With this in mind, Torreblanca recalled that early in 2006 the President of the Commission, José Manuel Barroso, addressed the EU Parliament with a wish list: "solidarity" in terms of economic and social cohesion; environmental sustainability; institutional responsibility; "security" perceptible by the citizens; and the promotion of EU values in the world. Even though the Council had accepted this political scope in mid-2006, the conclave held at the end of the year limited itself to the commemoration and the reaffirmation of the values of the European process.

Following the constitutional gathering organized by the Spanish government in Madrid, the difficulties of the process became increasingly evident. Though the Commission insisted on the endorsement and the social reinforcement of the five priorities expressed by Barroso, the UK expressed satisfaction with the EU's enlargement and the fall of the Berlin wall, while the Czech and Polish governments insisted on the insertion of liberalism, Atlanticism and the Christian roots of Europe. Whereas Sarkozy's proposal of a mini-treaty was surpassed by a majority soliciting a "Constitution-plus", the alarm sounded when signals from London indicated that the Labour party would avoid the "Europeanization" of the election in 2008 at all cost. Ironically, the strategy of respecting the "red lines" in order to anchor the UK in the EU was no longer valid. Among other reasons, this is because these privileges have enraged the Left in countries like France. In fact, the French "no" made the UK referendum practically impossible. Although representative of only a minority in the overall picture, Belgium and other states would push for provocation of the unthinkable.

Finally, after much speculation and last minute details, language reformulation and in-depth analysis, the Declaration was issued, reflecting a minimal consensus and a strategy developed by the presidency that had limited success. The very short text (barely 650 words) had an introductory section in which the EU congratulates itself on its accomplishments. It deals with the combination of the rights of "the individual", the uncertainty of the world arena, and then outlines the EU's most valuable dimensions. Finally, Section III of the Declaration returns to the "unification" of Europe as a dream of "earlier generations" that has now become a reality. However, history reminds us that we must "always renew the political shape of Europe in keeping with the times." That is the reason why today we are "united in our aim of placing the European Union on a renewed common basis before the European Parliament elections in 2009." In any event, the Declaration pledges once again that "Europe is our common future." 
Although the word "constitution" was dropped from the text, it still read as having the intention of finding a solution for a documentary commitment to the spirit and purpose of the Constitutional Treaty. The time frame provided a temporal context for the "road map" which is supposed to be issued at the end of the German presidency in June of 2007. Skeptics evaluated this compromise simply as a postponement of the thorniest issues, such as those detected by the Polish government regarding the voting system. The same can be said about the diplomatic compromise to gloss over the European socioeconomic "model", a source of conflicting interpretations during the disastrous ratification process in France and the Netherlands.

In anticipation of this uncertain scenario, certain sectors of Spanish analytical and governmental communities recommended that the remaining valid option was to take on a more aggressive position, sending warning messages, and to wait for the looming possibility of an unconvincing or very controversial Declaration or for a call for a subsequent IGC with unknown results. The worse case scenario could be a "rupture of the system or selective demolition of the process" (Torreblanca 6).

In the Spanish domestic context, two issues might had, both in theory and practice, posed obstacles for the development of an effective strategy towards this goal. The energy of the Spanish government might be eroded in the future for two reasons. One is the potential lack of consensus about the nature of the European mission, crafted by the two main political parties. Considering the continuous harassment by the Popular Party since its defeat, the temptations to use the EU stalemate to attack the PSOE and to show a lack of support remain a possibility. This confrontation would then be staged within the context of the elections to be held before March 2008 (a limit according to the electoral law). However, the benefits of the risky policy executed by the Popular Party are negligible in comparison with the potential to develop a minimal level of support. The second source of danger was reflected by the pressure of the latest wave of ETA terrorism, derailing the announced truce with the bombing of the Madrid airport parking lot. Although the attention given by the Spanish government to this problem is paramount, expert opinions indicate that it can still achieved with a strong commitment to the European project.

\section{$\underline{\text { Conclusion }}$}

In terms of the constitutional process and its possible outcomes, what do all of the above alternatives represent for Spain? Both sets of scenarios, the catastrophic one outlined in some analytical calculations and the variations that could develop based on the potential paths to be taken, were, in some ways, positive for Spain on the grounds that, at all times, whatever decision were made, there would be a strong emphasis on the defense of the investments made until then. Spain did not have anything to lose by applying pressure and insisting on the continuation of a positive process that called attention to the spirit of the constitutional path and its most necessary 'container' (the "ship"). By abandoning the strategy and tactics followed until then, Spain would be "rewarded" either with a less favorable position in the future of the EU or with being labeled as a supporter of a potentially dying dream. While still seeking to maintain a 
strong leadership position, and in the event of a catastrophe, the Spanish government and its collaborators could simply point to the fact that they did their best.

For the above reasons, the Spanish government maintained a solid commitment first to the salvaging of the letter and the spirit of the constitutional treaty. Then a basic consensus developed at the end of the German presidency showing that a strong majority of Member States were in favor of supporting a script presented by Chancellor Angela Merkel regarding the complete abandoning of the constitutional path. The choice then was to approve the skeleton of a "reform" treaty. Madrid then sent clear signals that there were some fundamental aspects that should be respected from the spirit of the constitutional treaty. It then acted as a loyal partner in supporting the German initiative and leadership, which was praised by Spanish commentators ${ }^{15}$ and then forming a practical coalition with the new French president in convincing the hardliners (Poland and the United Kingdom) that a compromise was in order. ${ }^{16}$

The scholarly and media reaction to this outcome revealed that a substantial majority expressed general satisfaction, stressing the positive dimensions of the solution, based on the fact that it included the most fundamental institutional reforms envisioned in the defunct constitutional text (Martín, Torreblanca 2007, Mangas 2007). A notable number of observers and media editorials pointed out to areas of concern (El País 2007, "El nombre"; Baquero). A strong minority expressed anger and deception for the path taken by the Union, casting doubts over its prospective future regarding the limitations of the supranational aim and the perceived return to the intergovernmental logic (Sotelo, Vidal Folch). Overall, government and analytical sources targeted the negative role of the Polish government in resisting making a deal over the final text ${ }^{17}$ expressing fears of impact over the drafting of the "Reform Treaty" (of Lisbon) and its ratification process in 2008, on time for its implementation in 2009.

\section{References}

Abellán, Victoria y Blanca Vilá. Lecciones de Derecho Comunitario Europeo. Barcelona: Ariel, 1993.

Albertí Rovira, Enoch; and Eduard Roig Molés (eds.) El proyecto de nueva Constitución Europea: balance de los trabajos de la Convención sobre el futuro de Europa. Barcelona: Institut d'Estudis Autonòmics, 2004.

Aldecoa Luzárraga, Francisco. La integración europea. Madrid: Tecnos, 2002.

Aldecoa Luzárraga, Francisco. Una Europa. Su proceso constituyente 2000-2003. Madrid, Biblioteca Nueva, 2003.

Aldecoa, Francisco. "El proceso político europeo en la laberíntica ratificación del Tratado Constitucional”. Real Instituto Elcano. DT, 16 febrero 2006/1

\footnotetext{
${ }^{15}$ See Sentís.

${ }^{16}$ See Missé, Egurbide 2007

${ }^{17}$ El País 2007, “Nosotros”.
} 
Aldecoa, Francisco. “La CIG confirma el tratado constitucional de la Convención”, Real Instituto Elcano de Trabajo, 1 setiembre 2004.

Almarcha Barbado, Amparo (ed.) Spain and EC membership evaluated. London: Pinter, 1993.

Areilza Carvajal, José M. España y las transformaciones de la Unión Europea. Madrid: FAES, 1999.

Baquero Cruz, Julio. “Europa entre la unamidad y la utopía”, El País, 31 junio 2007.

Barbé, Esther, and Elizabeth Johansson (eds). Beyond enlargement: the new members and the new frontiers of the enlarged European Union. Barcelona: Universitat Autónoma, 2003.

Barbé, Esther. La política europea de España. Barcelona: Ariel, 1999.

Barón, Enrique. Europa en el alba del milenio. Madrid, Acento Editorial, 2000.

Bassets, Marc, “Zapatero aparca la Constitución europea”, La Vanguardia 16 junio 2007.

Bassols, Raimundo. España en Europa: historia de la adhesión a la CE, 1957-85. Madrid: Política Exterior, 1995.

Borrell, Josep; Carlos Carnero y Diego López Garrido. Construyendo la Constitución Europea: Crónica Política de la Convención. Madrid: Real Instituto Elcano, 2003.

Calonge Velásquez, Antonio. La Unión Europea: guiones para su enseñanza. Granada: Comares, 2004.

Carnero, Carlos, y José Ignacio Torreblanca, “Europa, todos al tren”, El País, 26 junio 2007.

Chari, Raj S., Alfonso Egea de Haro, Kenneth Benoit and Michel Laver. "Spain and Europan Union Constitution Building”. Real Instituto Elcano, DDT, July 18, 2004.

Closa, Carlos, and Paul Heywood. Spain and the European Union. NY: Palgrave, 2004.

Closa, Carlos. "La ratificación de la Constitución de la UE: un campo de minas" Real Instituto Elcano, ARI No. 13, ago-set 2004.

Closa, Carlos. "Quo vadis, Europa? Seis opciones para una crisis constitucional”, Real Instituto Elcano, ARI, no. 23, julio 2005.

Crespo MacLennan, Julio. Spain and the process of European integration, 1957-85. NY/Oxford: Palgrave, 2000.

De Ayala, José Enrique. “Europa en la encrucijada”. Política Exterior, 103. Noviembre / Diciembre 2005. pp. 13-21.

De la Cruz Ferrer, Juan; José Carlos Cano Montejano. Rumbo a Europa: la ampliación al este de la Unión Europea: repercusiones para España. Madrid: Dykinson, 2002.

Egurbide, Peru. “España planta cara a la pretensión de Blair”, El País, 20 junio 2007.

Egurbide, Peru. “Zapatero quire reducir al máximo las opciones del veto en la UE”, El País, 16 junio 2007.

El País, "El nombre de la cosa”, 24 junio 2007.

El País, "Nosotros, los Kaczynski”, 28 junio 2007.

Esteve, Francina, and Montserrat Pi. La proyección exterior de la Unión Europea en el Tratado Constitucional. Barcelona: CIDOB, 2005.

European Council. “A Citizen’s Agenda: delivering results for Europe”, COM 2006211.

Farrell, Mary. Spain in the EU: the road to economic convergence. NY: Palgrave, 2001.

Fernández Navarrete, Donato. Historia y economía de la Unión Europea. Madrid: Centro de Estudios Ramón Areces, 1999.

Font, Joan. "El voto de los españoles en el referéndum sobre Tratado Constitucional”, Real Instituto Elcano. ARI, no. 22, junio 2005.

Freixes, Teresa, y José Carlos Remotti, El futuro de Europa. Constitución y derechos fundamentales, Valencia: Minim, 2002.

Gillespie, Richard, and Richard Youngs. Spain: the European and international challenges. London: Frank Cass, 2001.

González Vallvé, José Luis. “La construcción europea”. Política Exterior, 106. Julio/ Agosto 2005. pp. 1320.

Granell, Francesc. Catalunya dins la Unión Europea: Política, economía i societat. Barcelona: Edicions 62, 2002.

Información Comercial Española. Las políticas comunitarias: Una visión interna. 20 años de España en la Unión Europea. No. 831. julio-agosto 2006.

Jones, Rachel. Beyond the Spanish state: central government, domestic actors and the EU. NY: Palgrave, 2000.

Kerr, John. "Pick the sweetest European cherries”. Financial Times, Feb. 28, 2007. 
Kurpas, Sebastián. “Qué aspectos de la Constitución Europea podrían salvarse si fracasa la ratificación? Los problemas del "Plan B”." DT No 26-2005 - 27.5.2005.

León, Bernardino. « Un nuevo Gobierno, una nueva política exterior », Real Instituto Elcano ARI, No. 13, agosto-setiembre 2004.

López Castillo, Antonio, y Molina, Ignacio. “Memorando Opex № 28/2007: La Convocatoria en Madrid de los “Amigos de la Constitución europea”. 24 enero 2007.

López Garrido, Diego. La Constitución Europea. Alicante: Bomarzo, 2005.

Lorca, María. 2007, “The euro turns five”, Miami/Florida European Union Center, EUMA, February 2007.

Mangas Martín, Araceli. “Reflotar Europa tras hundir la nave constitucional” El Mundo, 25 junio 2007.

Mangas Martín, Araceli. La Constitución Europea. Madrid: Justel, 2005.

Mangas, Araceli, y Diego J. Liñán Nogueras. Instituciones y derecho de la Unión Europeas. Madrid: Mc.Graw-Hill, 1996.

Mangas, Araceli. “El rescate del Tratado Constitucional: ¿qué y cómo se puede salvar?”. Real Instituto Elcano, - ARI No 17/2007, 12 febrero 2007.

Marks, Michael. The formation of European policy in post-Franco Spain: the role of ideas, interests, and knowledge. Avebury, VT: Ashgate, 1997.

Martín y Pérez de Nanclares, José. "Hacia un Nuevo tratado europeo: de cómo recuperar la esencia del Tratado Constitucional sin que lo parezca”, ARI, Real Instituto Elcano, 9 julio 2007.

Méndez de Vigo, Iñigo El rompecabezas: así redactamos la Constitución Europea. Madrid: Biblioteca Nueva/ Real Instituto Elcano, 2005.

Missé, Andreu, “España y Francia impulsan una iniciativa para ‘sacar a Europa del estancamiento' “ El País, 18 junio 2007.

Montes, Pedro. La integración en Europa: del Plan de Estabilización a Maastricht. Madrid: Editorial Trotta, 1993.

Morata, Francesc. La Unión Europea: Procesos, actores y políticas. Ariel: Barcelona, 1998.

Moreiro, Carlos J. “Entre la Convención y la CIG: el diseño de la nueva Europa”. Política Exterior, 95. Septiembre / Octubre 2003, pp.105-112.

Moreno Juste, Antonio. Franquismo y construcción europea. Madrid: Tecnos, 1998.

Muñoz de Bustillo, Rafael, y Rafael Bonete Perales. Introducción a la Unión Europea: un análisis desde la economía. Madrid: Alianza,1997.

Navarro, Alberto. "La Europa de los ciudadanos”. Política Exterior, 103. Enero / Febrero 2005. pp. 73-80.

Ortega y Gasset, José. Obras completas. Madrid:Revista de Occidente.

Petschen, Santiago. “Aceptar el fracaso” Política Exterior, 106. Julio / Agosto 2005. pp. 77-88.

Petschen, Santiago. “Europa: ¿Estados o ciudadanos?”. Política Exterior, 98. Marzo / Abril, 2004.

Petschen, Santiago. La construcción europea: una visión desde la perspectiva del poder. México: Plaza y Valdés, 2005.

Pipes, Richard. "Spain and the European Union”. The major nation-states in the European Union. NY: Longman/Pearson, 2005, pp. 302-319.

Política Exterior. Editorial. “Sí español a la Constitución”, No. 104. Marzo / Abril 2005, pp. 5-6.

Powell, Charles. “El gobierno español ante el proyecto de Tratado Constitucional”. ARI No 90-2003 23.6.2003.

Powell, Charles; José Ignacio Torreblanca, Alicia Sorroza. Construir Europa desde España: los nuevos desafíos de la política europea Madrid: Real Instituto Elcano, 2005.

Rodríguez Iglesias, Gil Carlos y José Ignacio Torreblanca. "El futuro de la Constitución europea: opciones para España”. Real Instituto Elcano, 2006.

Roy, Joaquín, and Roberto Domínguez, eds., 2006 Towards the Completion of Europe: Analysis and Perspectives of the New European Union Enlargement. Miami: European Union Center/Jean Monnet Chair, 2006.

Roy, Joaquín. “La Unión Europea: de la arquitectura a la alquimia,” in Joaquín Roy, Roberto Domínguez and Rafael Velázquez (eds.), Retos e interrelaciones de la integración regional: Europa y América, México: Universidad Nacional de Quintana Roo/Plaza y Valdés, 2003, pp. 53-77.

Roy, Joaquín. "Spain's Return to "Old Europe": Background and Consequences of the March 11 and 14, 2004 Terrorist Attacks and Elections". Miami European Union Center/Jean Monnet Chair. Vol. 5, No. 6, March 2005. www.miami.edu/eucenter/royaznarfinal.pdf

Roy, Joaquín; and Aimee Kanner. "España y Portugal en la Unión Europea". México: Universidad Autónoma de México (UNAM), 2001. 
Roy, Joaquín; and Aimee Kanner. "Spain and Portugal in the European Union", The European Union and the Member States: Cooperation, Coordination, and Compromise. Eleanor E. Zeff and Ellen B. Pirro (eds.) Boulder, CO: Lynne Rienner, 2001, pp. 235-263.

Ruipérez, Javier. La "Constitución Europea” y la teoria del poder constituyente. Madrid: Biblioteca Nueva, 2000.

Ruiz Jiménez, Antonia María y Víctor Sanpedro. “La Constitución Europea en la prensa española de ámbito nacional: un análisis comparativo de El País, El Mundo y ABC”. DT Nº 1-2005 14.1.2005.

Ruiz Jiménez, Antonia María, and Javier Noya. "Los españoles ante el Tratado Constitucional y el proceso de integración europea”. Real Instituto Elcano, DT, 12 diciembre 2004.

Sampedro Blanco, Víctor Francisco, Antonia María Ruiz Jiménez y Bruno Carriço Reis "El referendo del Tratado de la UE en la prensa española de referencia: a favor de la Constitución o en contra de la Unión Europea”. DT No 20-2005 - 29.4.2005.

Sánchez-Gijón, Antonio. “Consecuencia del 'no’”. Política Exterior, 106. Julio / Agosto 2005, pp. 21-26.

Sebastian Royo, Paul Christopher Manuel, editors. Spain and Portugal in the European Union : the first fifteen years London/Portland, OR: Frank Cass, 2003.

Secretaría de Estado para la Unión Europea, Ministerio de Asuntos Exteriores y de Cooperación. "El futuro de la Unión Europea: Informe del Gobierno al Congreso de los Diputados”. DT No 2-2006 9.2.2006.

Secretaría de Estado para la Unión Europea, Ministerio de Asuntos Exteriores y de Cooperación. "Reflexiones sobre el futuro de la Unión Europea (II). Actualización del Informe del Gobierno al Congreso de los Diputados “; DT No 8/2007 - 28/02/2007.

Sentís, Carlos. "Merkel levantó la antorcha”, La Vanguardia, 29 junio 2007.

Sotelo, Ignacio. "Europa, la gran derrotada”, El País, 6 julio 2007.

Tamames, Ramón. La Unión Europea. Madrid: Alianza, 1994.

Torreblanca, José Ignacio, y Alicia Sorroza. "Principales datos sobre el proceso de ratificación de la Constitución Europea en España”. DT No 8-2005 - 21.2.2005.

Torreblanca, José Ignacio. “¿Quién teme a la Convención?” ARI No 77-2003 - 26.5.2003.

Torreblanca, José Ignacio. “El ‘Plan B’ de la Constitución Europea: ¿mirar hacia el otro lado?” Real Instituto Elcano, ARI, no. 23, julio 2005.

Torreblanca, José Ignacio. “El referéndum sobre la Constitución Europea en España: una doble decepción”. Real Instituto Elcano. ARI. Marzo 2005.

Torreblanca, José Ignacio. “España toma la iniciativa europea ”. ARI No 8/2007 - 23.01.2007.

Torreblanca, José Ignacio. “Europa vuelve a funcionar”, ARI. Real Instituto Elcano, 25 junio 2007.

Torreblanca, José Ignacio. “Tiempo de aniversario, tiempo de trincheras, riesgo de ruptura.” ARI No $16 / 2007$ - 12.02.2007

Torreblanca, José Ignacio. The reuniting of Europe: promises, negotiations and compromises. Aldershot: Ashgate, 2001.

Valcárcel, Darío. “Sí a la Constitución europea”. Política Exterior, 103. Enero / Febrero 2005. pp. 81-87.

Vidal-Folch, Xavier. “Rapto y rescate de Europa”, El País, 8 julio 2007.

Villapadierna, R, “Zapatero ofrece flexibilidad a Merkel”, ABC, 16 junio 2007.

Viñas, Angel. Al servicio de Europa: Innovación y crisis en la Comisión Europea. Madrid: Universidad Complutense, 2006.

Viñas, Angel. Las políticas comunitarias: Una visión interna. 20 años de España en la Unión Europea. Madrid: ICE, 2006. 